\title{
Politic Control of Public Administration from Assembly of Kosovo
}

\author{
Mervete Shala \\ Phd (cand.), University Haxhi Zeka Peja Kosovo \\ mervete.shala@unhz.eu
}

\section{Doi:10.5901/ajis.2015.v4n2s1p138}

\begin{abstract}
In this paper was treated political control of Pubic Administration as a politic-judicial process of continuous supervision by the Government and Independent Agencies of Assembly of Kosovo. The aim of the paper is the research of political control of administration as a factor with an influence on functioning of sustainable, professional, efficient, functional, responsible, transparency and accountability of administration for better governance in Kosovo. Republic of Kosovo in its Constitution, Chapter 4 has set out the assigning of powers, control and the balance between them, but in practice, it has been shown that this level toward the respect highest of the act hasn't been reached yet. In the Assembly of Kosovo in two former legislations of its sessions in a few cases the influence (control) of the Government toward the Assembly was evident. Government and political parties in power blocked the regular functioning of the Assembly. Abandoning or nonparticipation in Assembly sessions (boycott) by the Government and the political powers forced the Head of Parliament to interrupt the session due to lack of quorum. Such acts happened upon the request for constituting of ad hoc commissions for control of executive or independent agencies during the interpellations, etc. Relying on the said cases, we came to a conclusion that in several cases the Government had a control upon the Assembly and not vice versa. This was a bad practice of parliamentary and democracy functioning and representing of citizens' rights. Research questions-What factors had an influence for not instructing fair control Parliament of Kosovo toward the Government Independent Institutions? Hypothesis-Unwillingness of political will to politic control of Government and Independent Institutions. In some of legislations, one weak minor opposition was not strong enough to carry on the role of supervision. Unwillingness for parliamentary investigation and constituting of investigation commissions for the government and independent agencies, thus, all this has led to revealing of many corruptive acts, misuse of official tasks and public scandals regarding the functioning of administration. In current and future legislations the rise of political will of parliamentary authorities to political control is recommended as a mechanism of parliamentary democracy and each state authority has to carry on its constitutional commitment. The methodology of this paper is of mixed nature, such as; descriptive, research, explanation and foreseeing methods.
\end{abstract}

Keywords: control, Assembly, Government, fair governance, accountability

\section{Introduction}

The assembly as a state body is the carrier of the most important state and political functions. The Assembly is the highest representative institution and has three main functions such as; as a legislative function electoral and supervising function. Legislative function is the right to adopt the laws which govern the country. Article 65 of the Constitution of Kosovo has determined that the Republic of Kosovo Assembly,approves the constitution, laws, ratifies international treaties, resolutions and other general acts. Electoral function is in the competence of the Assembly to elect and dismiss the main state carriers Referring also to the named above article of the Constitution, Parliament exercises supervisory function using control instruments such as budget approval, periodic reports, parliamentary interpellation, parliamentary questions, polling committees, institute of government impeachment and Government's dismissal.

In what way has the Assembly exercised function of control during 4 legislatures? The Assembly during the first legislature (the first term of Assembly from 2001 to 2004) didn't carry out its constitutional mandate to control the government and independent institutions that have constitutional obligation to report to the Assembly for reasons of broad coalitions of the Democratic League of Kosovo (LDK), the Democratic Party of Kosovo (PDK) and the Alliance for Future of Kosovo (AAK), the lack of parliamentary experience and other circumstances under the administration of UNMIK. During the second legislature (the second term of Parliament from 2004 to 2007) there was opposition and coalition, the Assembly took the role of supervisor and parliamentary opposition use a number of instruments of control, as the parliamentary question, interpellation and setting up the investigation committee During the third legislature (third term of the Assembly from 2007 to 2010) there was a coalition between the two major parties in Kosovo, Democratic League of Kosovo (LDK) and the Democratic Party of Kosovo (PDK) and a minor opposition which was powerless to enhance the 
supervisory role Assembly. For this reason the control was almost minimal for the government and independent institutions from the Assembly. During The fourth legislature (Assembly mandate quarters from 2010 to 2014) there was a coalition between the Democratic Party of Kosovo (PDK) and New Alliance New Kosovo (AKR) and some smaller parties and those communities have a great opposition which was coordinated as they strengthen the role of the control function of the Parliament either by: submitting a large number of parliamentary questions, parliamentary interpellation to the Prime Minister and ministers of the Government Cabinet. During the mandate of this legislature there was increase of the investigation committee, irregularities of current electric tariffs, there was also an attempt to raise the no-confidence vote from the government party Alliance for the Future of Kosovo (AAK) which is not supported by other opposition parties and on May 7, 2014 the Assembly with 2/3 voted for dissolution of the Assembly, i.e. termination of the mandate.

First legislature 2001-2004, and 2004-2007 Legislature second term, the mandate of delegated was three years as determined by the Constitutional Framework. Third legislature 2007-2010 and 2010-2014 Fourth legislature these last two legislatures constitutional mandate of deputies is four years, but due to the successful motion of confidence to the government in 2010 ended prematurely mandate and on May 7, 2014 Assembly by a 2/3 vote of the Assembly vote in distribution, ie termination of mandate.

The goal of the paper is the research of political control of the administration as a factor that affects the functioning of sustainable public administration, professional, efficient, functional, responsive, transparent and accountable, for fairer governance in Kosovo.

This paper is structured as follows: in the first part we have analysed the meaning literature for political control of public administration. In second part of the relevant literature we reviewed and analysed the legal standards for political control of public administration after the war period 1999.During the period of administration of Kosovo by UNMIK and the governance after the Declaration of Independence of Kosovo. In this part were treated instruments of parliamentary control in Kosovo, we have conducted the analysis of the use of ordinary and extraordinary control over four legislations. Finally, we have presented the conclusions and recommendations.

Methodology of the research paper have relied on primary and secondary sources, analysis of all legal documents on which political control of public administration for the Assembly and the Assembly reports and Progress reports and monitoring of institutions who supervise the work of the Assembly and rely on the secondary sources in the literature.

\section{Politic Control of Public Administration in Kosovo}

Constitution of the Republic of Kosovo has clearly defined article 4 and article 63 (Chapter IV) The Assembly is the legislative institution of the Republic of Kosovo directly elected by the people. Also article 65 Constitution in Competencies of the Assembly provide as: the Assembly approves the budget of the Republic of Kosovo; elects and dismisses the President and Deputy Presidents of the Assembly; elects and may dismiss the President of the Republic of Kosovo in accordance with this Constitution; elects the Government and expresses no confidence in it; elects members of the Kosovo Judicial Council and the Kosovo Prosecutorial Council in accordance with this Constitution; proposes the judges for the Constitutional Court; oversees the work of the Government and other public institutions that report to the Assembly in accordance with the Constitution and the law; gives consent to the President's decree announcing a State of Emergency etc. (Constitution of the Republic of Kosovo Articles 63 and 65).

Political control of the administration of the Assembly is a form of a control performed to administration (executive). According to Professor Bajrami "Parliamentary Control of the government is a political and legal process, which ensures a constant political supervision of government by the Assembly"( Bajrami, 2010: 110). Likewise, Professor Stavileci "emphasised that "with parliamentary control it is particularly aimed: ensuring the regular functioning and the fair administration; guarantee legality and protection of the rights of citizens and exercise general supervision over administrative activity" (Stavileci,1997, 124). Parallel with representative and legislative function, the supervision of the government and carrying of its responsibility is considered one of the main responsibilities of all democratic parliaments. First of all, it is the right and the responsibility of parliament which represents the interests of citizens to constantly monitor the performance of the executive branch. In every country with developed representative democracy, legislative bodies have specific mechanisms through which supervise the work of executive institutions. The primary aim of institutions is to enable citizens through elected representatives to hold the government accountable for its actions and omissions or successes and failures.Whereas,the second goal is to enable members of parliaments to verify how applicable and useful are approved laws on policies. The laws and public policies adopted by Assembly do not always reach the goal for which they were created, due to compilation errors, obstacles in implementation or because of socioeconomic changes in place. Thus, as part of the supervisory function, Assembly must verify the implementation of 
policies and laws, identify obstacles and setbacks, and propose necessary measures for their proper implementation. At the same time, the Assembly has broad powers in supervising the efficient functioning of these institutions and supervising the implementation of effective parliamentary application of the laws. The lack effective parliamentary supervision, particularly, in countries in transition is often regarded as one of the reasons for the failure of democratic systems of government. In general, effective parliamentary role of supervision consists of: supervising the work of the executive institutions and independent institutions, overseeing the implementation of laws and concrete measures for their non-implementation; holding the government accountable for the way of spending the budget, taxation of citizens, respectively, resulting in increased efficiency and effectiveness; proper implementation of government policies and programs; promotion of transparency and accountability in governance, and increase of citizens confidence in state institutions (Manual oversight function of parliamentary committees, Pristina, June 2012, p.7). Parliament The highest representative institution in Kosovo and with the premise of a democratic institution of the first constitution Legislature after the war in Kosovo, has been constantly facing challenges and problems for the construction of an institution as a pillar of $s$ democratic value $s$ in Kosovo. Unfortunately, numerous democratic problems are accompanied nowadays. Inability to implement the legislative plan of his work, poor quality of the approved laws, extremely poor parliamentary control over government failure to monitor the implementation of laws in practice, degradation of the recommendations or views of the Assembly of the Government, are the facts which in no way could empower this institution to carry out its obligations under powers guaranteed by the legal order in Kosovo ( Progress Report Made in Kosovo, organizations that have drafted this report KCSS, GAP, FPC, KDI and IPOL, October 2010,Pristina, p.10).

\section{The Instruments of Parliamentary Control in Kosovo}

Government of the Republic of Kosovo is responsible for implementation of state laws and policies and is subordinated to parliamentary control. Moreover, the mandate of the parliamentary control of the Assembly is not limited to supervising the work of the Government, but it includes other public institutions, which, according to the Constitution and laws of the report to the Parliament of Kosovo (Scorecard Parliament of the Republic of Kosovo I-VI / 2013 p.5).In a parliamentary democracy, supervision of implementation of laws is as important as their adoption process. Although the supervision of the implementation of laws is conducted by civil society, public institutions are responsible only to the findings of supervised activities to alter into concrete steps to change the factual situation. Through enforcement law supervision, the Assembly can ensure information about practical implementation of laws and require political responsibility from the holders of institutions if it is learned that implementing institution haven't met the responsibilities assigned by Law. (Manual oversight function of parliamentary committees, Pristina, June 2012, p.20). The Assembly is using its instruments of parliamentary control, such as budget approval, periodic reports and Government ad-hoc, parliamentary questions, interpellations, polling committees, institute impeachment and dismissal of the government he performs its constitutional mandate to supervise, i.e. political control. Assembly has in disposal regular instruments and extraordinary parliamentary control.

\subsection{Regular tools of Parliamentary control}

Parliament throughout its entire term has in disposal instruments ordinary and extraordinary parliamentary control. Assembly held in disposal regularly instruments such as the adoption of the budget and periodic reports which the Government is obligated to submit to the Assembly for its work.

\subsubsection{Budget approval and periodic reports}

The Assembly while approving the budget, it has decided about the amount of revenues and expenditures of the public budget. The approval should not be only a formal task simply performed for being in accordance with Constitution. Generally Assembly is an appropriate place for financial accountability. Competition for power on the budget is common, but the tension between the two institutions is recognized as one of the essential controls and balances of democracy. If the Constitution and the law of the budget are adequately designed, the power of one authority reinforces the other. Elected parliament holds "the power of the wallet", ex. authorizes all expenditure, all loans, and all revenues to be collected through the power of the state (Managing of public expenditure, MF and GTZ, Tirana 2004: 65). Allen Schik, well-known researcher in the area of budgeting has suggested that budgets can have three different purposes which are reflected in all the budget treatments. These purposes are the planning, management and control. According to Schick, 
any attempt to reform the budget changes the balance between the three goals and sometimes due to carelessness and sometimes on deliberately (Denhardt \& Janet,2010 pp.255-256). The Assembly of Kosovo approves the budget of the Republic of Kosovo. By approving the budget the Parliament defines public revenues and public expenditures, where the Government implements the program provided in its mandate. In many countries the budget is approved at the end of the year, in December, when the Government is enabled to start with the calendar year from January 1 to start with the new budget. Professor Komoni states the' budget approval for one year is the appropriate time for the reason that the budget shall be the reallocation of national income generated during one year. It is considered as a period in which more easily and accurately can be set the needs to be fulfilled and the necessary means to finance these needs (Komoni,2008, $p$. 219). However, there are cases in practice when the budget is not adopted at the end of the year due to several reasons: Assembly members and government have not agreed on the division of the budget in particular sectors or about forecasting public revenue insurance where in the provided draft the privatization of state assets is more important (vital) for the state, or even when the draft is not prepared in certain legal deadlines, change of government, the economic and financial crises, cases where a country is in negotiations with international financial institutions and in cases when natural disasters occur in a country. Parliament is entitled to approve the budget, the delegates of the Parliament in occasion of Budget approval it enables them to make a political control over the government and its work.

Professor Bajrami emphasises that"not rarely during the year the Government requires budget amendments and filling through re-balance while demanding additional funds to be allowed by Parliament. Such demands are the result of the costs financial means allowed on the budget, and as a result of adding additional financial requirements of the state administration"( Bajrami,2002, p.142). The Assembly has a central role in supervising the spending of public money. Efficient supervision of budget execution helps to improve the management practices with the state budget, of the gap between available money and spending money, and most importantly for the country to prevent the corruption. The Assembly budget supervision also helps to better understanding the budgetary needs of specific sectors and not penalize the budget allocation budget organizations which are not properly spend the allocated budget in the previous year (is budget surplus or poor planning). (Manual oversight function of parliamentary committees,Pristina, June 2012 p.31).

After approval of budget distribution by the Assembly, the Constitution of Kosovo, the Law on Budget, Law on Public Financial Management and Accountability and the establishing laws of independent institutions, mandating institutions, obligate independent and executive institutions to report on a regular three-month basis and annual expenditures and budgetary revenues.The Law on Budget for each fiscal year also provides regular reporting on expenditures and budget revenues in presence of The Assembly and Committes (Ibid, p. 33). The Minister shall prepare and the Government shall review quarterly reports covering the fiscal year through the end of the quarter just ended. Such reports shall be submitted to the Assembly within thirty (30) days from the end of each quarter and then published by the Minister (Law No. 03 / L-048 Article 45). At least twice a year, during the review of six (6) months report and final reporting on closure of the fiscal year, the Minister based on this register shall report on budgetary amendments and adjustments occurred during the Fiscal Year. For example, any time when it is requested by the Assembly, the Minister shall, on behalf of the Government, present to the Assembly a comprehensive report detailing and reconciling the approved budgetary appropriation for 2014, all subsequent transfers and other changes and the final budgetary appropriations for the Fiscal Year 2014 (Law No.04 / L-233,Article 3). The Government is required to submit to the Assembly a report on each budget organization within thirty days after such report is presented to the Government by the related budget organization.(Article 44.6 of the Law No.03/L-048 ). The Minister shall prepare and the Government shall review quarterly reports covering the fiscal year every completed quarter. Such reports shall be submitted within 30 days from the end of each quarter and then published by the Minister.(Manual supervising function of parliamentary committees, Pristina, June 2012, p.34) In typical parliamentary systems, the government is obliged to inform its work reports to Assembly through its periodic work reports. Periodic reports which the government submits to parliament, represent instruments of political control, with which parliament supervises the implementation of laws and the state policy of government. Periodic reports usually including the period of 6 months and one year. In parliamentary practice, the institute of government savings is known for the first 100 days of its work. The reports of government work as a rule submitted in written form and presented by the Prime Minister. Submission of periodic reports of the Assembly to the government, can often serve as a basis for opening of opposition action debate related to the responsibility of the government, which could result in a motion for a vote of confidence for the government.(Bajrami, 2005,p.103)

\subsection{Extraordinary means of parliamentary control}

Extraordinary instruments are used "ad hoc" from time to time and as a rule present an instrument of opposition action 
toward government criticism within the framework of the political confrontation in parliament.(Bajrami,2005, p.103)

Extraordinary instruments of parliamentary control are parliamentary interpellations, questions of delegates of the Assembly, parliamentary investigating committee the motion of the government and the dismissal of the government. How are these extraordinary instruments of parliamentary control in Kosovo, according to the Rules of Procedure of the Kosovo Assembly?

\subsubsection{Parliamentary control through parliamentary interpellations}

According to article 44 Rules of procedure of the Assembly of the Republic of Kosovo outlines that Parliamentary Group six namely (6) Members of Assembly or more may file a motion of interpellation to debate an issue related to the work of the Government or a Ministry. The session of the Assembly when an interpellation shall be limited to a maximum of three (3) hours. An interpellation motion shall be submitted in writing and it should include: a concise formulation of the issue; a justification for the motion; the name and authorized signature of the Parliamentary Group in question and text of the motion proposed for voting. The motion of interpellation is forwarded to the President of the Assembly, within two days, after its receipt, the President shall forward it to the Prime Minister or the Minister, to whom the motion is addressed. The Prime Minister or the Minister shall be obliged to review the motion within seven (7) days. The interpellation shall be included in the Agenda of the plenary within seven (7) days after the receipt of the answer by the Government. The Prime Minister or the minister to whom the request is addressed shall be obliged to present and argue the opinion of the Government regarding the issue raised by interpellation. The interpellation debate may not be carried over to the next session of the Assembly. An interpellation on the same issue may not be submitted more than twice during a calendar year.(Rules of procedure of the Assembly of the Republic of Kosovo Article 44). Interpellation as a mechanism of supervising of executive branch is used very little in Kosovo. It is worth pointing out that during the first legislature 20012004 and up to June 2006, the Parliament of Kosovo was held only a parliamentary interpellation.(Over 10 years of parliamentarism in Kosovo,KDI 2013,p.16). However, even though the delegates of Kosovo The Assembly is entitled to supervise parliamentary control of the government through parliamentary interpellant aiming to review an issue that is the competence of the Government activity in general, or of one Ministry in particularity. In spite of existence of this right, which in countries with consolidated democracy is considered as one of the most important instruments of parliamentary control of the Government, the Assembly or delegates nor in 2010 haven't used this form of parliamentary supervision.(Progress Report Made in Kosova,organizations that have drafted this report are: KCSS, GAP,FPC, KDI and IPOL, October 2010, Pristina. p.11).

Parliament of the Republic of Kosovo, during the third legislatur, held four interpellations, speech by the President Dr. Krasniqi Jakup on the activities of the Assembly during the 2008-2010, in the year-end meeting with reporters and editors.(Parliament of the Republic of Kosovo 30.12.2010,the third legislatur). In 2011 the Prime Minister was called in three interpellations and one interpellation the Minister of Trade and Industry. (The legislative activity of the Assembly in 2011 (February-December 2011) The Assembly, 22 December 2011, the Legislature IV). Although, in practice is applied the boycott of Assembly by the Government and delegates of the political party in power in the plenary sessions when the agenda were the interpellations of ministers, particularly at the time when the Parliament proposed voting of one motion point, (ex. Interpellation of the Ministry of Trade and Industry). In this session President of the Assembly found that in the hall were present 56 delegates. He said that in the absence of a quorum cannot continue with the proceedings with the vote of a motion filed by delegates .(The plenary meeting of the Assembly of Kosovo, held on 12 and 13 July 2012, the Legislature IV). Assembly had discussed about four interpellations even in 2012 on the issue of missing persons, the process of privatization, export tax foreign policy, which were held in accordance with Article 44 of the Rules of Procedure of the Assembly. Two of four motions have resulted in a approved by the Assembly for the Government. Even in this case, the adoption of recommendations by the Parliament was the closure of the supervisory process, as the sponsor of interpellations didn't any action to further convey for application of these recommendations.( Report of the Monitoring Procedure of the Assembly of the OSCE July, 2013 p.7). During 2013 three (3) motions were conducted, speech by the President of the Parliament, Dr. Jakup Krasniqi, in the year-end meeting with the media (Parliament of the Republic of Kosovo, December 2013, the Legislature IV)

From the first quarter of 2011 to December of 2013 the Assembly had 11 Parliamentary interpellations. In the fourth legislature the number of parliamentary interpellations significantly increased toward the control of the Government. Anyway, the ruling coalition parties in most cases at the end of the debate reached with their votes against, not to adopt raised motions by the applicants or the initiators of interpellations, which even made them to lose the importance of this democratic instrument.(Over 10 years working parliamentarism in KDI 2013, p.16). 


\subsubsection{Parliamentary control through parliamentary questions.}

Procedures for parliamentary questions as a supervising mechanism of Government are set out by the Rules of Procedure of the Parliament of Kosovo. Rules of procedure of the Assembly of the Republic of Kosovo Article 45 provide any member of the Assembly may ask a question, to be answered orally by a member of the Government, provided that such question is tabled in writing at the Table Office, at least forty-eight (48) hours prior to the session. A member of the Assembly who has filed a question in accordance with the Rules of Procedure of the Assembly, shall have the right to ask the question to the Government even if the member of the Government is absent or has not prepared a reply. A question addressed by a member of the Assembly to the Prime Minister may be deferred by him/her to one of his ministers at his/her discretion. If a question has not been answered within 2 sessions, the question will be published in the Bulletin of the Assembly and on the official website of the Assembly, while the Information Office of the Assembly shall issue a Press Release within 24 hours, after the second session. Also article 46 determine Members of the Assembly may submit questions for written answer to the Prime Minister or any other Minister, about his or her area of responsibility. The answer shall be given within two (2) weeks from the date the question was submitted, and shall be included in the records of the next plenary session of the Assembly. The list of unanswered questions within the required period of time shall be published in the bulletin of the Assembly and distributed to the members of the Assembly.( Rules of procedure of the Assembly of the Republic of Kosovo Article 45 and Article. 46).

The Assembly of the Republic of Kosovo, during the third legislature (2008-2010), submitted 915 parliamentary questions, speech by the President Dr. Jakup Krasniqi on the activities of the Assembly during the III (2008-2010), in the year-end meeting with reporters and editors (Parliament of the Republic of Kosovo 30.12.2010, the third legislatur). During the period March-December 2011, 124 parliamentary questions were submitted, among them 106 received a response, whereas 18 have been published in the Journal of the Assembly.(The legislative activity of the Assembly in 2011 (February-December 2011) The Assembly, 22 December 2011, the Legislature IV). During 2012, delegates of the Parliament submitted 160 questions to the Government for oral answer, of which 117 received a response from the Prime Minister or by the appropriate Ministers.Although 43 questions remained unanswered due to the absence of Ministers and the same were published in the of Parliament bulletin. Parliament activities in practice, the absence of Government during the questioning has created difficulties to the Assembly in time properly managing for filing of questions. Moreover, delays in answering the questions caused the loss of their importance. Anyway, Assembly has no mechanism to force the Ministers to answer questions raised by delegates of the Parliament. (Report of monitoring the work of the Parliament, the OSCE,Mission in Kosovo July, 2013, p. 8).

During 2013 over 190 were submitted parliamentary questions to the Prime Minister and to the Cabinet of Ministers, of which 56 parliamentary questions were answered and published in the journal of the Parliament. (Speech of the President of the Assembly, Dr. Krasniqi Jakup, in the year-end meeting with the media; see more: at http://www.kuvendikosoves.org/?cid=1,184,18).

During 2011 to December 2013 were submitted 474 questions for the Prime Minister and Minsters of the Cabinet, of which 357 were answered, whereas 117 questions remained unanswered and were published in magazine of the Assembly. Confusion of ministers to respond to questions and the absence of in parliamentary sessions where the issue of their work activities was tackled was an ignorance and disregard toward their official commitment for Parliament and recommendations and its stands. Civil society and citizens should be more active in political control of institutions while sanctioning their votes in the upcoming parliamentary elections to all those political forces which did not work in the interest of the citizens of Kosovo.

\subsubsection{Inquiry committees as a work tool for government control}

The Assembly may also use the instrument of constituting the inquiry committee as a mean of control for the work of the government. Law on parliamentary investigation Article 2 outlines that the Committee shall be established to investigate problems, issues that involve directly the responsibilities of the Government or State. The Committee shall be established with the aim to conclude, describe the flow of events in order to clarify what has happened and to define responsibilities of those involved in it. The Committee shall be established to inform, recommend, and exercise the parliamentary supervision and achievement of a conclusion. The Committee shall be established and functions on the basis of constitutional principles and rules defined by this Law. The Committee prepares the final report regarding the investigations within the given term by the Assembly and in compliance with the Law. Also Article 5 provide the Assembly decides for the intermission of the Committee work before the end of the mandate, this only by the request of the initiator 
(of the committee) and with the majority of votes by all deputies. In cases when the Assembly is dismissed before the end of the regular mandate, the Committee will also cease to exist. Issues that once have been an object of parliamentary investigation in one of the mandates of the Assembly cannot be again subject of parliamentary investigation, except in cases indicated when the Assembly is dismissed before the end of the regular mandate, the Committee will also cease to exist. The issue determined for parliamentary investigation can be subject of amendment by a decision of the Assembly or extended later by a decision of the Assembly, if the initiator of the Committee has agreed with that amendment. The Committee is obliged to respect to its given mandate by the Assembly (Law No.03/L-176 Article 2, Article 5 and Article 6). With the aim to fulfill the investigations, the Committee has the right: to summon the holders of public functions to be heard before the Committee and to summon other natural and legal persons to be heard before the Committee to give their testimony under oath; to have the absolute access in all official documents; to request hearing of evidence; to order for compulsory behavior of persons abovementioned to give their testimonies in front of the Committee; to establish an investigative group to develop specific investigations from members of the Committee. The Committee is entitled to ask for an independent experts' expertise while accomplishing their tasks. Financial means for this expertise shall be provided by the Assembly. The work of the Committee is supported by the Assembly staff (Law No.03 /L -176 Article 13). Despite what the law on parliamentary inquiry was adopted in 2010, the Assembly of Kosovo in the past had in disposal legal basis for the establishment of inquiry committees foe particular issues. This issue was regulated by the Rules of Procedure of the Parliament adopted in 2005.Although, for more than a decade of Assembly operation, this instrument was used only in the first three cases. The first parliamentary inquiry committee was established to investigate the riots of March 2004. Although the commission held several consecutive meetings, the nature of the case under investigation, the political situation and the circumstances created influenced fail of the committee to conclude the investigation of the case and drafting a report for the Assembly of Kosovo.

The second case was when the Kosovo Parliamenty established a commission of inquiry in relation to the factual findings of the Auditor General for 2005 to unfold a series of serious financial abuses by the leadership of the Parliament. Relying on fair level of cooperation between the members of the commission coming from opposition parties and those in power, the committee had managed to compile a final report which was submitted to Assembly with concrete recommendations for consideration and approval. The recent established inquiry parliamentary commission related to the billing of electricity consumption for January 2013, established by decision of the Parliament of 28/03/2013.(More than 10 years of parliamentarism,drafted by KDI, published in 2013, pp.16-11). During 4 legislations of the Assembly there was a lack of the readiness and political willingness to establish an ad hoc inquiry committee to reveal several corruption affairs and official abuse by some public officials.

\subsubsection{The motion vote of confidence the government and dismissal of government}

Institute of vote confidence of the Government represents the leading institution of parliamentary control, which raised the political responsibility of Government in Parliament. This powerful instrument with which Assembly exercises the means of control over the Government and the instruments with which the issue of political control directly raised. Unlike all other parliamentary instruments (questions of delegates, interpellations, parliamentary polling commissions), which are only instruments of political control of the Government, the Government institute is a mechanism by which the question is directly addresses the responsibility government policy.(Bajrami,2005,p.112).Constitution of the Republic of Kosovo Article 100 provide motion of no confidence the Government. A motion of no confidence may be presented against the Government on the proposal of one third (1/3) of all the deputies of the Assembly. A vote of confidence for the Government may be requested by the Prime Minister .The motion of no confidence shall be placed on the Assembly agenda no later than five (5) days nor earlier than two (2) days from the date it was presented.The motion of no confidence is considered accepted when adopted by a majority vote of all deputies of the Assembly of Kosovo. If a motion of no confidence fails, a subsequent motion for no confidence may not be raised during the next ninety (90) days. If a motion of no confidence against the Government prevails, the Government is considered dismissed (Constitution Article 100).

Dismissal of Government presents the last instrument of political accountability of the Government, through which the Assembly takes mandate of the government, as e result of non-confidence.Thus, in cases vote confidence in parliamentary procedure. The Government according to the power that the law is considered dissolved. Dissolution, in the legal sense is a kind of sanction that the Assembly undertakes toward the Government, as a result of nonaccomplishment of the program, which previously had taken confidence in the Assembly. (Bajrami,2005, p.116). Kosovo Assembly in November 2010 approved by majority the votes of no-confidence motion against the government led by 
Prime Minister Hashim Thaçi and Kosovo went to the polls to extraordinary polling. Motion of vote of confidence was filed by a small party (Alliance for New Kosovo, AKR ) coordinated by the party in power. The motion of vote confidence was contrary by the Assembly Members. Members of the party in power of justified pro motion as the excess of the parliamentary crisis, whereas the members of the opposition as a result of bad governance of the Cabinet. In the Assembly of Kosovo there was an attempt had raise for motion of no confidence against the government of Thaçi, the past days by the members of party of Alliance for the Future of Kosovo (AAK). This attempt for providing of the signatures of assembly failed to reasoning that other opposition parties are not well supported to achieve the signing of the assembly members was unable to provide enough votes for motion of no-confidence against the government and the government did not have the votes to vote the most important issues that were on the agenda of the Assembly sessions. The biggest political party in power (PDK) and the opposition during several meetings reached the agreement to move the initiative for dissolving of the Assembly and go to extraordinary elections as the best possible solution of the created situation.

The third legislature quarter 2007-2010 and the fourth legislature 2010-2014 in these last two legislatures constitutional mandate of assembly members is four years, but due to the successful motion of confidence of the government in 2010 ended with prematurely mandate, and May 7, 2014, the Assembly by a 2/3 of votes, voted for the dissolution of the Assembly, ie the termination of the mandate.

\section{Conclusions}

During the past Legislatures in Kosovo, the Government-executive authority in several sessions dictated the parliamentary agenda such as; not taking part in the sessions of ruling government parties in the Assembly of Kosovo (unstable position) did not participate (boycotted) in the sessions of the Assembly considering that the opposition had more votes (delegates in the room) and the decisions will go favour of the opposition. Their absence in the session, and in this way locked the institutional activity of the Assembly. For this reason, the Chairman of the Assembly for lack chuorum was compelled to terminate the sessions until another decision, particular case in parliamentary practice. In democratic countries the opposition party boycotting the work of the Assembly is evident on many occasions in parliamentary countries, but not the ruling party and the government to boycott Assembly sessions. Whereas in Kosovo, the opposite happened, it was the ruling party which abandoned the sessions. Assembly delegates of the past position were asked to abandon the Assembly sessions by their leaders, that is to interrupt the meeting.Although it can be considered as a political control of the parliamentary political group in power. However, Constitution of the Republic of Kosovo Article 70 provide Deputies of the Assembly are representatives of the people and are not bound by any obligatory mandate.

Demand (order) to abandon the session is evaluated as a violation of the freedom and independence of the assembly delegates.

The Assembly of Kosovo, also, during the past mandates didn't use control of instruments so much, particularly interpellations as a way of government supervision due to the inability to provide the number of delegated to search for the motion.

Especially parties in power-the government at a time when there was not a majority of votes of the assembly, it didn't attend the assembly sessions, then when the motions were raised; when it was required to vote for the recommendations of motion; when it was requested the election of board members, members of independent commissions etc.

Setting out of parliamentary supervising mechanism of the Cabinet began to lose its importance they have for the reason that in many sessions of the Assembly, Ministers of various sectors were missing when the questions were directed to them about their sectoral issues and in a way the Assembly ignored its recommendations.

In Kosovo there are estimates of no political readiness for political control of the executive, parliamentary investigation commissions for ad hoc inquiry committees, in independent Agencies was an obstruction for revealing of many corruptive facts, abuse the official position and controversial in public scandals.

During this and the future Kosovo Assembly mandate it should (it is recommended) to use all the mechanisms of government supervision and exercise its constitutional mandate, to be effective in its supervisory function by disabling the Government to control the Assembly.

In the fifth legislature (2014-2018) and the next Assembly should ask responsibility and accountability from the prime Minister and the Government Cabinet when reluctant to answer parliamentary questions and ignore the opinions of the Assembly recommendations.

Political control of the public administration should be performed more often and depending on cases, because it 
increases the credibility, professionalism, effectiveness, efficiency, fair governance, accountable, transparent and accountable in serving the citizens of Kosovo.

In the fifth legislature (2014-2018) the raise of the political will is recommended of the parliamentary political parties for political control as a mean of parliamentary democracy and every state body should carry out its constitutional mandate.

Increased political will,readiness for parliamentary investigations, setting up of (ad hoc) investigating committees, in the independent Agencies which presents the prevention and fighting of corruption, abuse of official duties in public administration.

Civil society and citizens should be more active in political control of institutions condemning with their votes all those political forces which did not work in the interest of citizens. Strengthening of the control mechanisms of public administration is a good hope for the future of Kosovo to establish the rule of law with more functional institutions and democratic society as a condition for integration into the European Union.

\section{References}

Bajrami, Arsim, (2002) ,"The rights of Kosovo in transition", Pristina,

Bajrami, Arsim, (2005),"Parliamentary Democracy (Comparative aspects)", fourth edition, Prishtina,

Bajrami, Arsim, (2010), "Parliamentarianism (Comparative aspects)", Pristina,

Robert B. Denhardt \& Denhardt V. Janet, (April 2010),Public administration, action-oriented, the sixth edition, English edition II, Publishing House, University UF O. Press, Tirana,

Sabahudin, Komoni, (2008), "Public Finance", Pristina,

Stavileci, Esat, (1997), " Introduction to administrative sciences " Pristina,

The Constitution of the Republic of Kosovo approved the 09.Prill 2008 entered into force on 15 June 2008; Official Gazette, No. 03, date of publication in the Official Gazette 06/2008, Pristina.

Law No. 04 / L-165 on Budget of Republic of Kosovo for year 2013 Official Gazette No 36/2012 Published ( OG) 21.12.2012

Law No.04 / L-233on Budget of Republic of Kosovo for year 2014 Official Gazette No.1/2014 Published (OG) 09.01.2014

Law No. 03 / L-048 on public Financial Management and Accountability No. GZ ordinal 27 Date of publication in the Official Gazette (OG) 03.06.2008

Law No.03 / L -176 on Parliamentary Investigation Official Gazette of the Republic of Kosovo / Pristina: Year V / NO. GZ 74 ordinal date of publication in the Official Gazette / 20 July 2010

Rules of procedure of the assembly of the Republic of Kosovo, Pristina, 29 April 2010

Manual oversight function of parliamentary committees, Pristina, June 2012

Over 10 years working parliamentarism in Kosovo Democratic Institute (KDI) 2013 Published by: Forum 2015 - operational project of KFOS

Progress Report Made in Kosovo, organizations that have drafted this report are: the Kosovo Centre for Security Studies (KCSS), FOL Movement, the Institute for Advanced Studies GAP, Foreign Policy Club FPC), Kosovo Democratic Institute (KDI) and the Balkan Policy Institute (IPOL). October 2010 Pristina

The legislative activity of the Assembly in 2011 (February-December 2011) The Assembly, 22 December 2011, the Legislature IV

Report of the Monitoring Procedure of the Assembly of the Organization for Security and Cooperation in Europe (OSCE) mission in Kosovo July, 2013

Minutes of the plenary meeting of the Assembly of Kosovo, held on 12 and 13 July 2012, the Plenary of the Parliament P-71,Pristina, on 12 July 2012

Speech by the President of the Assembly of Kosovo, Dr. Jakup Krasniqi, in the year-end meeting with the media for the work of 2013; See widely with: http://www.kuvendikosoves.org/?cid=1,184,182

Speech by the President Dr. Jakup Krasniqi on the activities of the Assembly during the III (2008-2010), in the year-end meeting with reporters and editors to extensively look at: http: //www.kuvendikosoves.org/? Cid = 1,184,94

Scorecard Assembly of the Republic of Kosovo I - VI / 2013

Public expenditure management, (2004) prepared by the Ministry of Finance with the support of GTZ, Tirana 